\title{
Research into Value Chain of China's Music Industry
}

\author{
Lin Yu and Hong Deng \\ Scientific Research Office, Jiangxi University of Technology
}

Keywords: China's music industry, industry's value chain, piracy, digital music, profit model

\begin{abstract}
Due to serious piracy, music industry develops slowly in China with malformed profit model and a lack of complete industrial value chain. With the rapid development of the Internet and mobile network technology, digital music has gradually replaced traditional records and become the form of mainstream music products, and digital-music-related industry has rapidly become the core of music industrial chain. Digital music has rewritten the value chain of traditional music industry, and digital music industrial chain will become the development direction of music industry. Thus, it is possible for China's music industry to get out of its piracy dilemma and usher in health development by grasping this direction. Therefore, it is of great significance to China's music industry by analyzing music industry's evolutional trend from traditional model to digital model. In this paper, through analysis, it is found that the biggest problem face by China's music industry is piracy, which has caused the lack of complete value chain in China's music chain and makes China's music industry to choose malformed profit models. In order to solve the problem of piracy, this paper analyzes causes of piracy in detailed as well as its harm and treatment. While China's music industry is affected by piracy, the rapidly developing digital music also brings great impact on China's music industry from another prospective.
\end{abstract}

\section{Introduction}

Music industry is a branch of cultural industry. The promulgation of new concept and new policy about the development outline especially cultural affairs and cultural industry at the 16th National Congress of the Communist Party of China indicates a specific direction for China's cultural industry. Faced with the rapid economic development, China, with limited resources, must put it on agenda as soon as possible as how to timely develop smokeless industry and sustainable development of this industry, which is demonstrated by the 16th National Congress's decision to vigorously develop cultural affairs and cultural industry.

Behind the prosperity of music industry, an important part of cultural industry, there are many hidden problems, and all these eminent problems restrict the healthy development of China's music industry. Thus, it is an inevitable requirement to research theories of the entire music industry from perspective of industrial chain systematically for the development of music industry.

The current development of China's music industry is that: serious piracy, lack of value chain and malformed profit model.

In the traditional model of music industrial chain, the main source of profits is to distribute CDs and tapes. However, in China, due to the rampant piracy, disorder of the audio-visual market as well as that customers have not developed the habit of purchasing authentic CDs and tapes, this main industrial value chain is almost ruptured. 
In this case, a malformed profit model emerges in China's music industry: to earn money depending on singers' performance like shooting advertisements and TV series instead of selling records. It can be called a high irony that record companies do not rely on selling records to earn money, resulting that singers do not pay attention to improving their singing, thus their performance becomes poorer. The music industry has already lost its core product and the most valuable asset: music, which will cause the music industry to demise in the ling run.

The malformed profit model of China's music industry and the lack of complete value chain has brought various problems to China's music industry, but all these problems have been ignored by people until now, or people only comment and lament on it without researches proposing solutions from the economic perspective.

This paper researches the value chain of China's music industry while digital music is divided into two types: online music and wireless music. Due to piracy, the development of online music is restricted, and it still focuses on cultivating users with very broad prospective for development. Due to restrict protection of copyright, wireless music has become the major source of profit for digital music industry and completely changed the value chain OF China's music industry.

\section{Traditional Model of Music Industry's Value Chain}

According to retrospect of the development of music industry as well as analysis of source of value for traditional music industry, we can make a preliminary outline of traditional model of music industry's value chain, which is as shown in Fig. 1:

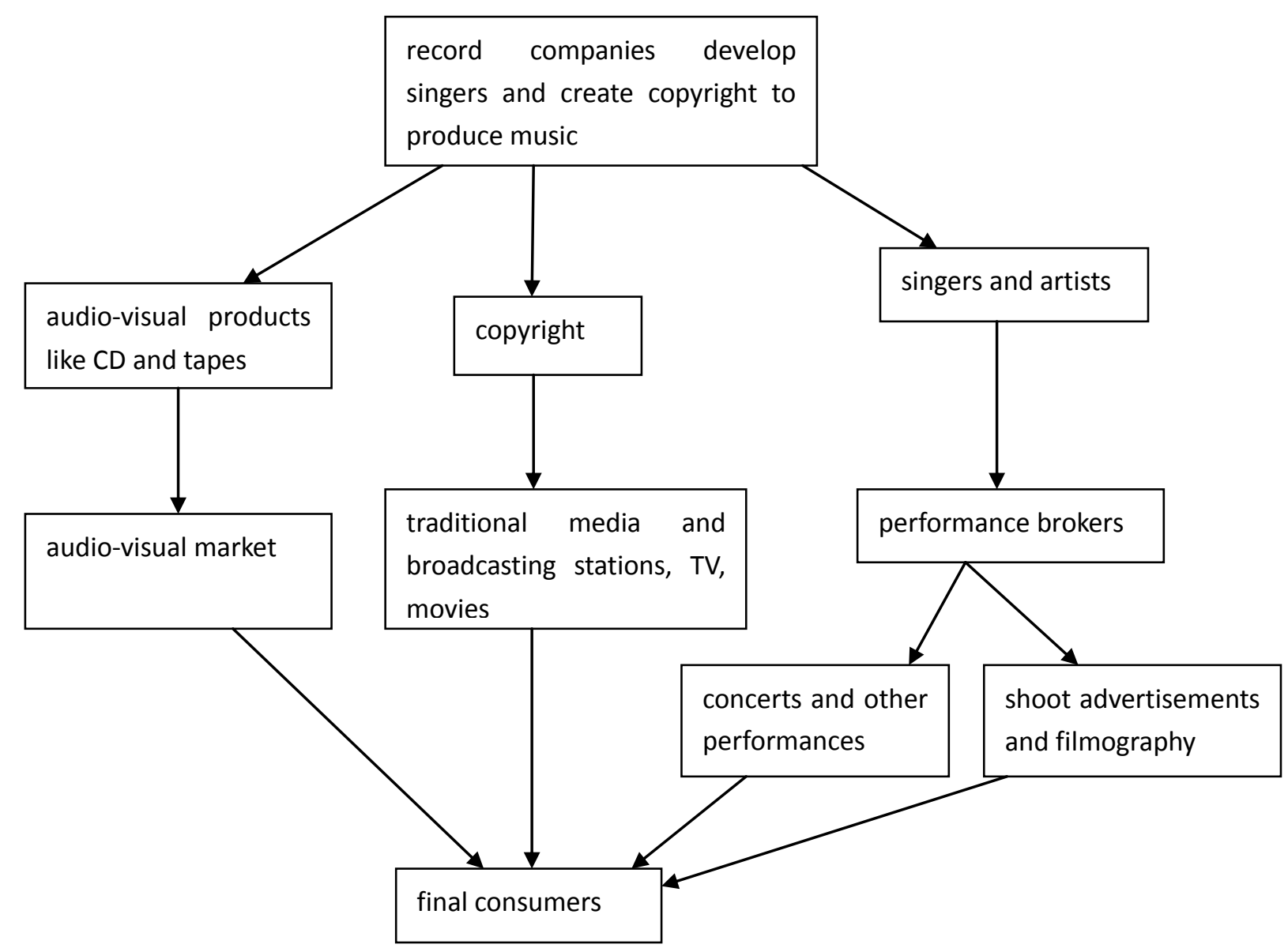

Fig. 1 Traditional Model of Music Industry's Value Chain 
As shown above, the upstream business of the music industry, but also the core of the music industry, record companies. The record company is making music production companies, they by finding talented singer-loved music creation, and made music copyright. Therefore, music, copyright and singers record company's core assets. The record company profits through the operation of these three assets to grow.

The No.1 value chain is the main sales channel of the music industry and international record companies to recover costs, main way of achieving profits. In short, it is selling records. Record companies will copy music on $\mathrm{CD}$, tape, to the video distribution company sales. Consumers buy music in the audiovisual market, access to their favorite music.

The No. 2 value chain is the main channel of communication and advocacy for music industry. Record company sold the rights to a variety of music media, such as radio, television, film, licensing them for broadcast. Media is not only a record company profits, they played more music publicity and promotion role. Record company needs media publicity for their products. As the media has a vast audience, media recommendation has a great impact on customers as what kind of music they will listen to. Wide play of music in a variety of media means appreciating music becomes more and more convenient. Given the experience of music, free media playback, so that consumers can "free trial", and to buy the love of music. So, in between music and mass media quickly found their market position, and this album - the media consumption patterns of industrial development--music deep into the cultural and economic areas.

The No.3 value chain is further development of derivative chain of the music industry. Singers themselves have huge commercial value, record companies through cooperation with brokerage firm, arrange singers participated in various performances, commercials, film work and earn huge profits. Singers perform not only through tickets, and paid direct revenue can also be obtained through the performance of consumers love, and incentives for consumers to buy more records. Therefore, strictly speaking, the commercial performance of the singer is also a marketing campaign on record, and their ultimate goal is to increase album sales.

The above 3 value chains have constituted the main frame of traditional models of music industry's value chain. Record company gets benefits through the record store, copyright and singer. Among them, the media and artists, both record companies' revenue streams and main means of publicity, promotional CD sales, music and copyright are a record company's core product, record companies the main profit comes from sales records and copyright. In the industry value chain and business model on the basis of forming a traditional development model of the music industry.

\section{Malformed Development of Traditional Model of Music Industry's Value Chain in China}

Through finding and comparing various materials, we have found that there are many problems in the development of China's music industry, such as the lack of vigorous support from the government, senior management and operation talents as well as perfect commercial operation mechanism, etc. However, under current circumstance, Chinese music industry lacks the most is a sound legal system and copyright protection mechanism, China's piracy is the biggest problem facing the development of the music industry, the weakest link in China's music industry is to release market.

Piracy is a worldwide problem, but is most prominent in China. In the United States, copyright issues of music mainly from online file-sharing in China, illegal CD production plants, such as pirated CD sales is very serious. 
In August 2005, the IFPI (International Federation of the Phonographic Industry) publicized the top 10 countries with the most serious piracy of music and showed that piracy in these countries had become insufferable. These ten countries are: Brazil, China, India, Indonesia, Mexico, Pakistan, Paraguay, and Russia, and Spain and Ukraine

The IFPI especially mentioned China in the report, thinking that $85 \%$ music products sold within China were pirated, and China was also the biggest pirated music market in the world.

Now, forms of piracy are constantly changing. CD piracy has become a major medium; piracy has become the groups, organized crime, and even gang involvement; piracy emerging delivery model of selling pirated goods; Internet pirating and infringement acts out of control. The past two years, the rise of P2P music file-swapping network suffers from physical erosion of China's music industry piracy more difficult.

Due to immature record market and serious piracy, the current development of music industry in China is: a lack of value chain, malformed profit model and reduced music level.

\section{Evolution of Music Industry's Value China from Traditional Model to Digital Model}

China Internet network information center (CNNIC) released the 1th statistical report on the Internet development in China was in 1997, as of October 31, 1997, the number of Internet users in China is 620,000, statistics and publishes twice a year thereafter. China Internet network information center reported in the "users" are defined as: Chinese citizens use the Internet for at least 1 hour per week on average.

China Internet network information center (CNNIC) survey released in July 2003, as of June 30, 2003, city, a growing number of Internet users in China has reached 68 million people. Internet access computers to 25.72 million units, number of Internet users was 9.8 million.

In June 1997, Zhang Qin created "Highland music communication" (www.gotitmusic.com) website. In July, the "Highlands" turn to paid applications outside international top-level domain and website, was the only top-level domain music website in mainland China, rapid expansion of space as $150 \mathrm{M}$ (this space is not at all easy at the time). Website to offer Real Audio real time music, BBS discussion groups, columns, other music information other than their own, and also contains a number of small and medium music styles are independent of each other Web site. In early 1998, "Heights" expansion of 400M, and opened a music chat room. By the end of 1998, the "Highlands" also made a new attempt to online sales of Chinese underground rock, sales of "fly", "Dawn", Wang Lei, the new record.

During this period of time, there were numerous other music sites, such as a frog music station (www.wanwa.com, the site also with well-known record company Shanghai audiovisual Publishing House, signed a contract of legal downloads of audio and video products, became legally able to download a lot of original music, especially to be able to download the most recent hit songs in the country's Web site.

Music sites have sprung up to grow up, and began to plunder the music market when media and record companies will finally wake up and join the creating Web sites in the procession. Channel v, MTV and other media using its own resources to run a "Chinese music network MTV" (www.MTV--China.com), with a background of the MTV support, quickly open the visibility in a very short time. China record Corporation to raise tens of millions of dollars, and approved by the State Council information Office, set up a "Chinese music site". The site will "sing" 70 years of accumulated resources move of excellent works on the Internet. While the other big domestic 
recording companies such as "audio", "Beijing", "modern sky" also opened or are opening their own music website.

In 1998, log on to the Internet, "East point pop music network" (www.epmusic.com..CN) became the first professional pop Web site, and its establishment marked a new revolution in pop music. At a time when pop music Web sites in full swing to develop and grow, some entities have joint development and entertainment industry, such as:

On February 25, 2000, Sohu company held at Beijing's capital Gymnasium called "millions of Sohu pride night" concert, to celebrate the second anniversary of the establishment of the company's birthday. Development of network entertainment and the entertainment industry becomes the new trends in the development of the network.

On September 26, 2000, Sohu worked together with Warner Music to their respective strength in the Internet and the entertainment industry, held in ten major cities of the country, "Sohu 2000 Warner stars easy-" National College Tour kicked off from the University campus. This event once again reflects the Internet music industry's development trend.

\section{Evolution towards Digital Model is the Inevitable Result of Technological Progress}

The development of information technology and the Internet is a huge effect on people's lifestyle, and change the way people enjoy music is only a very small one. If CD technology is no longer in line with people's life style, its sales decline and eventually disappear are normal things. Digital music's huge impact on development model of traditional music, record companies take legal actions to protect their copyright is necessary, but if you want to download music by cracking down on the Internet to save the music industry, you will fail sooner or later, because any deviation from the trend of the times people will become obsolete. In fact, in a sense, simply for the record companies had not found that lifestyle changes in a timely manner, not to open up the digital music business model will not be facilitating service users to think of ways to solve this problem. Record company and its taken against users of the "God" of the measure, might as well have a good look at the impact of technological progress and market opportunities.

Although the online music market in China by profit-sharing, the copyright struggle, policies and regulations, the impact of such factors as consumption habits, but the online music market continues to be bullish on online music has become in the next two years, broadband entertainment revenue one of the high-growth businesses. Comparing wireless service, broadband users accumulate and have great potential to provide multiple services. Current hot ringtones wireless music business music revolution of the tip of the iceberg, maturity of the operation mode of broadband online music in the field of music will bring the true meaning of subversion. New technologies and the emergence of new carriers bring about change in not just record sales, but also the whole industrial deep change. In the consumer music on mobile phones and the Internet will soon formally took to the stage of history, as our usual way of life.

Therefore, the huge impact of technical progress on the traditional record industry before, review the consumer's consumption habits and psychology, to adopt new technologies, develop new sales channels, establish a new protection mechanism recast the music industry value chain, and achieve a new profit model, is the top priority of China's music industry. Based on the current digital music in China's prominence in the music industry, we can foresee that era of digital music value chain of the music industry will be richer, more diverse, and related industries will be more and more involved. While the entire industry chain, broadband Internet and mobile communication network will replace 
the traditional media and the audiovisual market, a major channel of music distribution, marketing and communication.

\section{Conclusions}

Conclusion of this paper mainly includes the several aspects:

1. Value chain of the music industry is constituted of production, music distribution and spreading and final users. Herein, music production is made up of record companies and excellent music works are the core of music industry's value chain. Distribution and dissemination of music is the key to the value chain of the music industry links and links to value. In the traditional music industry, distribution and dissemination of music includes three parts: video marketing, traditional media and talent agencies. The audiovisual market is the main channel of the traditional record sales, traditional media such as radio, television is the main platform for music, promotion and talent agencies are an important source of music industry's huge gains.

2. Due to immature record market and serious piracy, the current development of music industry in China is: a lack of value chain, malformed profit model and reduced music level with piracy being as the biggest problem faced by the development of China's music industry.

3. Physical attributes of music products are three basic aspects: intangibility, loss-free and replicability. Economic features of music products are: experience commodity, scaled economic effect and public items. All these features of music products are the course of piracy suffered by music products. In the current situation, it is of great difficulty to totally eliminate piracy, but the correct and practical goal should be to restrict negative effects of piracy to the maximum degree.

4. No matter how advanced technologies are, music is still the core of value chain of music industry because without good music, it is no use to have the best commercial model. However, it is the inevitable road to form diversified value chain of music industry and promote the effective coordination and interaction between each links for the healthy development of the music industry.

\section{References}

[1] Ruan Hong. On Application of Music Commercialization in Current China's Society, People's Music 2003(1) 56-58

[2] Li Shiming. Construct Industrial Chain to Promote Industrialization. Social Edition of University of Electronic Science and Technology of China, 2002 (3) 75-78

[3] Yang Gongpiao, Xia Dawei. Modern Industrial Economics, Shanghai University of Finance and Economics Press, 1999, Page 46.

[4] Chen Bo. Industrial Chain and Development of Regional Economics, Industrial and Technological Economics, 1999, 18(5): 44-45

[5] Jiang Guojun, Research into Industrial Chain Theory and Stable Mechanism, Doctoral thesis of Southwestern University of Finance and Economics, 2004, Page 11.

[6] Yang Lin. Broadcasting, Popular Music and Recording Industry, Acoustic World, the 12th edition of 2003, 44-45.

[7] Zong Xiaojun. Secrets of Music Commerce. People's Music Press, 1999. 
[8] Xiao Shi. Exploration of Pop Music Record, International Music Communication, the 10th edition of 2002, 76-78.

[9] UNESCO And WIPO. Copyright Laws and Treaties of the World. The Bureau Of

National Affairs, Inc 1990,P108

[10]Wang Zeke, Sun Qunyan, Li Jie, Wa Li'an. On Information Market and Information Management. International Economic Review. The 32th edition of 2001.

[11]Bao Ang. Generalization of “Gresham's Law on the Software Market and Countermeasures. Journal of Changshu Higher College, 2000(1), 34. 